\title{
Human Rights in the Constitutions of the Gulf Cooperation Council Countries (GCCC): Texts and Realities
}

\author{
Samid A. Darawsheh \\ Faculty of Law, Irbid Private University, Irbid, Jordan \\ Email: Darawsheh83@yahoo.com
}

How to cite this paper: Darawsheh, S. A. (2020). Human Rights in the Constitutions of the Gulf Cooperation Council Countries (GCCC): Texts and Realities. Beijing Law Review, 11, 519-543. https://doi.org/10.4236/blr.2020.112032

Received: April 3, 2020

Accepted: May 24, 2020

Published: May 27, 2020

Copyright $\odot 2020$ by author(s) and Scientific Research Publishing Inc. This work is licensed under the Creative Commons Attribution International License (CC BY 4.0).

http://creativecommons.org/licenses/by/4.0/

\section{(c) (i) Open Access}

\begin{abstract}
This study addressed the issue of human rights in the constitutions of the Gulf Cooperation Council Countries (GCCC) by identifying human rights concept, development, and tracing the state of human rights within the GCCC countries through constitutional texts and practical application. The study is based on more than one scientific method to verify the hypothesis; it used the descriptive, analytical, and legal approaches. The study reached several conclusions, one being that there is no shortage in the contents of the constitutional provisions of the (GCCC) countries in terms of emphasis on human rights. However, practice in reality is different from theoretical texts. In the end, the study came up with several recommendations, including: the need for constitutional amendments in the constitutions of the Gulf Cooperation Council Countries (GCCC) so that the new texts include clear commitments to respect human rights, the inclusion of human rights concepts in the curriculum, and the use of all means, the media in particular, to spread the culture of human rights in the (GCCC).
\end{abstract}

\section{Keywords}

Human Rights, Constitution, Gulf Cooperation Council Countries (GCCC), Democracy

\section{Introduction}

The concepts of human rights began to emerge in the seventeenth century in the western part of the European continent, and they were widely used in the eighteenth and nineteenth centuries. The following decades and years saw great interest in human rights. They were referred to in the American and French dec- 
larations, or constitutions, as an essential part of human rights, as well as the establishment of national and international institutions concerned with human rights. In the twentieth century, human rights and related concepts and institutions became the motto of the stage. Human rights have evolved so much that the way the state treats its citizens is no longer an internal matter of the state alone. Based on the traditional understanding of the concept of national sovereignty that prevailed until the middle of the last century, human rights became a global affair for the entire international community, as these freedoms are an integral part of human rights, a prerequisite for human development, and a cornerstone of democracy as there is a close link between human rights and democracy $^{1}$ (Bani Salameh \& Darawsheh, 2018).

In the Arab world, popular and official interest in human rights began after the second half of the twentieth century. The Arab constitutions that emerged during that period reflected the concern for human rights. Many Arab constitutions stipulated respect for human rights ${ }^{2}$ (Bani Salameh \& Ananzah, 2015).

In the Gulf States, the concepts of human rights are included directly or indirectly in the constitutions of these countries; although, there are differences between the Arab Gulf countries in dealing with human rights. This study will attempt to address this through the recognition of the reality of human rights in the constitutions of the Gulf States, as the Constitution is the supreme law of the state, and the sure guarantee of the protection and respect of human rights. The study will also attempt to identify the reality of human rights in terms of practice and application in the Arab Gulf countries, and thus the difference between the theoretical texts in the constitutions and practice on the ground.

This study uses the analytical descriptive approach: to describe the provisions of human rights in the constitutions of the Gulf Cooperation Council Countries, and to identify the actual application of these provisions and their impact on the status of human rights.

For the purpose of this study human rights are defined as rights inherent to all human beings, whatever our nationality, place of residence, sex, national or ethnic origin, color, religion, language or any other status. These rights are all interrelated, interdependent and indivisible.

The Constitution is defined as the set of basic rules that define the form of the state, define its rules of government, establish basic guarantees of the rights of individuals, and regulate its general powers, with the terms of reference of these authorities $^{3}$ (Bani Salameh \& Ananzah, 2015).

\section{Literature Review}

Despite the paucity of previous studies that dealt with the relationship between ${ }^{1}$ Bani Salameh, Mohammed Torki and Darawshehl, Samid A. (2018). Human Rights in the Jordanian Constitution: Between Theoretical Texts and Practical Application. International Journal of Human Rights and Constitutional Studies. Vol. 6. https://doi.org/10.1504/ IJHRCS.2018.091658.

${ }^{2}$ Bani Salameh, M. T. and Ali Ananzah, A. (2015). Constitutional Reforms in Jordan: A Critica Analysis. Digest of Middle East Studies, 24: 139-160. doi:10.1111/dome.12068.

${ }^{3}$ Bani Salameh, M. T. and Ali Ananzah, A. (2015). Cstitutional Reforms in Jordan: A Critical Analysis. Digest of Middle East Studies, 24: 139-160. doi:10.1111/dome.12068.,Op.Cit. p.145. 
the Constitution and human rights in the GCC countries directly or indirectly, there are a number of studies that tried to approach the content and objectives of this study. The most prominent of these studies are the following:

Badriya Abdullah Al-Awadhi's study, entitled: "GCC Countries and International Levels of Work (1990)" (Al-Awadhi, 1990)

The study aimed at explaining the role of the international working standards in promoting human rights around the world through the set of principles and provisions agreed upon between countries and the code in the Conventions and recommendations of the International Labor Organization concerning the conditions of work and labor. The study shows how international efforts are successful in establishing these principles in national legislation through the monitoring and oversight bodies established by the International Labor Organization and the Committee of Legal Experts to implement and apply the international standards of action in the States parties to those conventions and the member States of the International Labor Organization. The study paid particular attention to the position of the GCC countries on the international working standards and how they are applied in these countries, based on the basic rule that human rights are an integral part of the fundamental rights and freedoms of man.

Faleh Sameeh Azzam's study, entitled: "Guarantees of Civil and Political Rights in Arab Constitutions (Comparative Study) (1995)"4 (Azzam, 1995)

The study aims to identify the state of human rights in the constitutions of the Arab countries, based on the tragic situation of human rights in the Arab world. Human rights in the Arab world are in a deplorable state, where strict control of freedom of opinion and expression and assembly. The Arab states follow the system of the modern state in terms of form and organization, but do not translate the values of the modern state governed by the law or the rule of law in their constitutions, which regulate the relationship of individuals with the state and authority. The study shows that the guarantees of respect for human rights in the Arab countries are not applied, despite the inclusion of provisions regarding human rights within Arab constitutions.

Naji Alloush's study, entitled: "Human rights in the Arab World: Theory and Practice (2002)"5 (Alloush, 2002)

The study aimed at addressing the issue of human rights in the Arab world on three levels:

- First: the level of official Arab and Islamic discourse, i.e. in the Arab and Islamic countries, and the speeches of events and the language of the media.

- Second: the relationship between the state, the people, and these freedoms.

- Third: practical practices.

On the level of human rights in the official discourse, the study considers that all Arab regimes try to claim that they are democratic, respect human rights ful${ }^{4}$ Faleh Sameeh Azzam. Guarantees of Civil and Political Rights in Arab Constitutions: Comparative Study (In Arabic). Cairo Center for Human rights Studies, 1995.

${ }^{5}$ Naji Alloush, Public Liberties in the Arab World, Human rights in Arab Thought: Studies in Texts, (In Arabic). Edited by Salma Al-Khudra Al-Jayyousi, Center for Arab Unity Studies, Beirut, Lebanon, 2002. 
ly, and prevent violating them by all means. Those who read the texts of the constitutions believe that the Arab countries are democratic states, and this is incorrect and unreal.

On the level of human rights in the state's relations with the people and international texts, the study shows that the Arab state is not enthusiastic about joining the international covenants and conventions related to the general freedoms, based on excuses and false arguments.

On the level of human rights in practice, the study considers that practice on the ground is the main criterion in judging any system, regardless of the provisions of the constitutions. The study considers that the state of human rights in the Arab world, as documented by the reports of organizations concerned with human rights, indicate that respect for human rights is not one of the priorities of Arab political systems.

Mohammed Al-Hamuri's study, entitled: "Rights and Freedoms between Political Ambitions and the Obligations of the Constitution: The Case of Jordan (2010)"6 (Al-Hamouri, 2010)

This study dealt with the reality of rights and freedoms in Jordan and the constitutional violations and temporary laws that were introduced, presented, and contradicted in many cases. It also tackled the power of the executive branch over the legislative power, and the weakness and inability of the representative parliament to block this change. The author highlighted the conditions of issuing provisional laws in the constitutions of the parliamentary system and the conditions of their issuance in the Jordanian constitution. He referred to the provisional laws issued by the government within 21 months when the 13th parliament was dissolved, and reached 160 laws that violated the legal system in Jordan. As well as the Political Parties Law No. 19 of 2007 from the perspective of constitutional freedoms, and the author described it as a punitive law that distinguishes between Jordanians and penalizes union leaders as well, and how the new law gave the government complete power over the parties' finances. The writer touched on the subject of political development and the supposed supervisory role of the House of Representatives, in light of the reality in Jordan, to protect the constitutional rights and freedoms, which must be the first step for reform.

Abdul Khaliq Abdullah's study, entitled: "Implications of the Arab Spring on the Gulf Cooperation Council Countries (2012)"7 (Abdullah, 2012)

The study aimed to identify the impact of the Arab Spring on the economically prosperous and, to some extent, politically stable countries in the Gulf, and how the Gulf states dealt with the so called the Arab Spring. Are these countries immune to the winds of change that have afflicted the region? How have these changes affected the security and balance of power in the Arabian Gulf? Have ${ }^{6}$ Mohammed Al-Hamouri, rights and freedoms between the whims of politics and the obligations of the Constitution: Case of Jordan, (In Arabic). Dar Wael Publishing and Distribution, Amman, 2010. ${ }^{7}$ Abdul Khaliq Abdullah, The Arab Spring Implications for the GCC Countries, (In Arabic). Arab Center for Research and Policy Studies, Doha, Qatar, 2012. 
they made the Gulf safer or less? The Gulf States always claim that they are not interested in the winds of change, that they have immunity against the democratic reform movement, and that it is an exceptional situation in the Arab world.

The study concluded that the GCC countries are part of the Arab regional system and that they will inevitably be affected by what is happening in the regional environment, and perhaps what happened in Bahrain is the best proof of this. The Arabian Gulf is part of its Arab environment, and it has one destiny and one future; when the moment of freedom arrives to the Arab region, it'll also arrive to the Gulf. There is no Arab state that has immunity, regardless of its wealth. The Arab land demands freedom from the Arabian Gulf to the Arab Maghreb, and the Arab peoples, including the Gulf region, are yearning for freedom, participation, democracy, and access to their civil and political rights in full and undiminished, and they deserve political and constitutional reform sooner rather than later.

Bani Salameh and Darawsheh's study, entitled: "Human rights in the Jordanian Constitutions: Between Theoretical Texts and Practical Application (2018)"' (Bani Salameh \& Darawsheh, 2018)

This study aims to identify human rights in Jordanian constitutions through a quick review of the development of human rights concepts in the world and the journey of the development of Jordanian constitutions. The results of the study showed that the Jordanian constitutions issued in 1928 and 1946 did not contain concepts of human rights as required, nor did they reflect the will of Jordanians looking for political participation, and fundamental freedoms. The 1952 constitution, which is currently in force, contains a range of civil and political rights for Jordanian citizens. This has been reinforced by a series of legislation regulating the exercise of these rights and duties of the state to ensure the enjoyment of them. However, practice on the ground shows a huge difference between the theoretical texts and the reality of human rights in Jordan. This requires ensuring that the provisions of the constitution are respected by all authorities as the surest guarantee of respect for human rights.

\section{Guarantees of the Exercise of Human Rights}

The human rights that were highlighted earlier may become mere ink on paper without the existence of guarantees that allow the implementation, and protection of these freedoms. There are several guarantees for practicing human rights; the most important are:

- First: the existence of a constitution for the state: The existence of a constitution that includes the rights and freedoms is the first guarantee for the maintenance and protection of these freedoms and establishing the legal system within the state. The Constitution explains the system of government in the

${ }^{8}$ Mohammed T. Bani Salameh and Samid A. Darawshehl, Human Rights in the Jordanian Constitution: Between Theoretical Texts and Practical Application. International Journal of Human Rights and Constitutional Studies. Vol.6. (2018). https://doi.org/10.1504/IJHRCS.2018.091658. 
state and indicates the status of public authorities and how they exercise these powers and the limits of their respective jurisdictions. The constitutional texts on the rights and freedoms of individuals are restrictions on the authority of the state.

- Second: Separation of powers: In the sense that there is a separation between the three authorities in the state: the legislative, executive, and judicial authorities, then there is a branch that is in charge of matters of legislation, one that is in charge of matters of implementation, and another that is in charge of judiciary matters. If this happens, each side has its specific competence, which cannot be overridden.

- Third: The principle of the incorporation of legal rules: It is established that the rules in the legal system of the state are not in a single rank in terms of their strength and legal value. These rules are ranked so that some of them are higher and stronger than others. This requires that the rule be subordinated to form and substance. Thus making the constitution at the top of these laws.

- Fourth: The supervision of the constitutionality of laws: they are carried out by political supervision or judicial control, each working to ascertain the compatibility of legislative and executive work with the provisions and principles of the Constitution, as the lack of conformity means the abolition of the law did not match the provisions of the Constitution.

- Fifth: Judicial control over the work of the administration: It shall be through the control of a judicial body or the so-called administrative judiciary, which monitors the work of the administration and the extent of their conformity with the law ${ }^{9}$ (Al-Shawi, 2006).

\section{Constitutional Provisions and the Status of Human Rights in Kuwait}

The Constitution of Kuwait is considered to be one of the oldest constitutions of the Gulf Cooperation Council Countries (GCCC). The Constitution was adopted at the end of 1962 under the reign of Prince Abdullah Al-Salem Al-Sabah. It adopts the parliamentary model of democracy. It establishes the existence of an elected council for a certain period of time. It's the product of past constitutional experience that Kuwait had undergone throughout its political history ${ }^{10}$ (Bani Salameh \& Al-Sharah, 2011). The Kuwaiti constitution is divided into five sections, comprising 183 articles $^{11}$ (The Kuwaiti Constitution). The articles on human rights are ${ }^{12}$ Article 7, 31, 35, 36, 37, 38, 39, 43 and 44.

\footnotetext{
${ }^{9}$ Munther Al-Shawi, The General Theory of Constitutional Law,(In Arabic). Dar Ward Publishing and Distribution, Amman, Jordan, 2006, pp. 302-305.

${ }^{10}$ Mohammad Torki Bani SALAMEH \& Mohammad Kanoush AL-SHARAH (2011) Kuwait's Democratic Experiment: Roots, Reality, Characteristics, Challenges, and the Prospects for the Future, Journal of Middle Eastern and Islamic Studies (in Asia), 5:3, 57-81, DOI: 10.1080/19370679.2011.12023185.

${ }^{11}$ The Kuwaiti Constitution.

${ }^{12}$ The Kuwaiti Constitution.
} 
Unlike many of its Gulf neighbors, Kuwaiti constitution has many provisions that enhance the status of human rights in the country. Articles 7 and 16 may be the most important articles that the Kuwaiti authorities have committed to since the implementation of the Constitution. The reason that they haven't been breached is because they do not go against special interests of influential people on the one hand, and that the ruling elites in Kuwait, on the other hand, are less inclined to force and the use of power tools, such as: harassment of capitalists for personal interests, or establishing influence and challenging simple people, or avenging any one $\mathrm{e}^{13}$ (Al-Najjar, 2000).

With regard to Article (31), it is noted that most laws and their applications fit the spirit of this article. Trials are open and relatively free, defendants have the right to appeal, and lawyers are appointed by the courts in criminal cases. The defendants are to be suspended for four days before being summoned to the investigating judge. Random arrests and detentions are rare, and convicts and prisons are in line with or above global standards ${ }^{14}$ (Human Rights in the Arab World, 2009).

The actual application of Article (35), as well as the laws related to it, in which the failure to meet the provisions of that article is very advanced; some laws and applications are in contrast with the concepts of religious freedom stipulated in the Constitution of Kuwait in analyzing the reality of. Dealing with the content of Article Twenty-ninth before (when talking about equal human dignity, non-discrimination due to religion $)^{15}$ (Al-Asiri, 2007).

In regards to articles (36) and (37), which deal with freedom of opinion and expression and freedom of publication; there is a restriction on that freedom in practice, despite the fact that the provisions of the articles do not contain any restriction. The law restricts freedom of the press and allows the obstruction of newspapers and the confiscation of their licenses. There are laws that enable the government to imprison journalists in cases of infringement. However, there are independent newspapers, and few indictments against journalists, and a law to jail journalists whose writings show contempt or mockery of religion. The Islamists used this law in several cases against some journalists and academics who explain their views as some derogatory of the value of religion in society and in some cases, this law is used to book the threat of judicial pleadings, or defamation, whether against writers or academics or against ministers and government officials $^{16}$ (Al-Asiri, 2007).

The applications and laws issued appear to be compatible with the contents of articles $(38,41,39,44)$, where there are no violations of these constitutional texts, according to reports, the press, and other media.

\footnotetext{
${ }^{13}$ Ghanem Al-Najjar, Introduction to Political Development in Kuwait, Kuwait, Dar Qurtas Publishing, 3, 2000, p.11.

${ }^{14}$ Human rights in the Arab World, Report of the Arab Organization for Human rights on the State of Public Liberties in the Arab World,(In Arabic). Center for Arab Unity Studies, 2009, p.17.

${ }^{15} \mathrm{Abd}$ al-Redha Ali Al-Asiri, Islam in the Constitutions of the Gulf Cooperation Council Countries, Arab Journal of Political Science, No. 13, 2007, Beirut, Center for Arab Unity Studies, p.130.

${ }^{16}$ Op.Cit.p.177. Human rights in the Arab World.
} 
The content of Article 39 may be considered in the traditional means of communication, but interference from the authorities supervising the Internet services results in blocking some of the pages that are described as unethical, but if the blocking process is for a specific reason, it may expand and others could use it as a bargaining power, as is the case in the Publications Act, or the Law on the Punishment of Disrespect of Religion ${ }^{17}$ (Abdul Qader, 2011).

Despite the fact that the contents of articles (43) and (44) are a manifestation of democratic action and an inevitable consequence of the long life of the parliamentary life of any society. Despite the fact that private sector workers are entitled to strike and that unions are legitimate, where only one union is allowed in every activity or profession, freedom of assembly and association is limited in Kuwait. The popular assembly requires government approval. The law also requires NGOs to obtain permission from the government, but in fact there are unauthorized organizations that have the freedom to organize themselves informally. Diwaniyas also represent unofficial meetings and create a climate for political discussions ${ }^{18}$ (Al-Galum, 1966).

The constitutional text of Article 43 contains essentially the word "bodies", which in general includes political parties, but the text is limited to the words of associations and trade unions and does not mention the word political parties ${ }^{19}$ (Bani Salameh \& Al-Sharah, 2011).

\section{Constitutional Provisions and the Status of Human Rights in Bahrain}

Bahrain has two constitutions in its modern history. The first was issued in 1973 shortly after Bahrain gained independence from Britain, but was abolished in 1975 by Prince Issa, who ruled under emergency laws until his death in 1999 (Al-Serhan et al., 2017). In 2002 King Hamad issued the 2002 Constitution which is valid so far; the Constitution consists of five sections and 125 articles $^{20}$. The articles on human rights in Bahrain's constitution are 7, 9, 19, 22, 23, 24, 25, 26, 27, 28 and $31^{21}$ (Bahrain Constitution).

Although the reform project of His Majesty King Hamad bin Isa Al Khalifa, which was launched in 2001, reaffirmed that the promotion and protection of human rights as an essential part of the Kingdom's strategy in developing state

\footnotetext{
${ }^{17}$ Wadan Abdul Qader, Kuwaiti Election Law, Critical Review of the Content and Influences of the Democratic Experience, (In Arabic).Arab Journal of Political Science, Beirut, Center for Arab Unity Studies, 31/2011, p.51.

${ }^{18}$ Yusuf Al-Galum, The Influence of the Dwyane on the Process of Political Participation in Kuwait, (In Arabic). Journal of Social Sciences, Kuwait, No. 3, 1966.

${ }^{19}$ Bani Salameh, Mohammed Torki and Al-Sharah, Mohammad Kanoush. (2011). Kuwait's Democratic Experiment: Roots, Reality, Characteristics, Challenges, and the Prospects for the Future, Journal of Middle Eastern and Islamic Studies (in Asia), 5:3, 57-81, DOI: $10.1080 / 19370679.2011 .12023185$.

${ }^{20}$ Sayel F. Al-Serhan et al., Challenges Facing National Security in the Gulf States: A Case Study of Bahrain. International Journal of Humanities and Social Science. Vol.7.No12. (2017). http://www.ijhssnet.com/view.php?u=http://www.ijhssnet.com/journals/Vol_7_No_12_December_2 017/15.pdf.

${ }^{21}$ Bahrain Constitution.
} 
institutions and national legislation, Bahrain's record on human rights has deteriorated sharply in the last years.

Almost all the articles of the new Bahraini constitution are literally quoted from the Kuwaiti constitution; therefore some articles will be re-analyzed, if their applications or laws are compatible with what happened in Kuwait.

Article (9) is not presented with the political and social orientation of the Bahraini society, so the applications and laws related to it will be very smooth.

Article (19) is the most powerful contradiction with which most of the texts link constitutional articles by restricting the violation of the provisions of the Islamic Shariah or any other restriction: in accordance with established customs, or in accordance with public order and ethics. These are all matters of jurisprudence, and the restrictions on personal freedom that the legislator said are guaranteed are found within these texts.

With regard to the application of Article (19), the situation has improved considerably with respect to the rights of citizens and residents not to be subjected to any harm or unjustified detention. Bahrainis are protected from arbitrary arrest and detention. The defendants are now granted, through protection procedures, reasonably open and impartial trials ${ }^{22}$ (Human Rights First).

Article 22, the first of which is vague: "Freedom of conscience is absolute". The explanatory memorandum is also ambiguous and appears to be a substitute for the phrase in article (35) of the Kuwaiti constitution states: "Freedom of conscience is absolute." Ensuring the state's inviolability of places of worship is consistent with the two major Islamic sects, with the continued control of the national Evangelical Church affixed to the American hospital, where Protestants also perform worship, and the proportion of foreigners is 38\%, mostly from South Asia and Arab countries. Close to non-Muslims (Christians, Jews, Hindus, Baha'is, Buddhists, and Sikhs), with the exception of those who pray in that church, they all perform their worship in private places without interference from the government and have to set up these special temples and display their religious symbols. Although the government is uncomfortable with proselytizing and banning non-Muslim writings, and the fact that the conversion from Islam to any other religion is not welcome, there are small groups practicing their conversion from Islam. On the other hand, other Christian gospels and publications are allowed to be traded, and there are no restrictions on the number of Shia pilgrims allowed to visit Shiite holy shrines in Iran, Iraq, and Syria. The non-Bahraini population in the past had difficulties in organizing trips to these destinations abroad, but the government has addressed this problem by granting these citizens between 9000 and 15,000 Bahraini citizenship ${ }^{23}$ (Public Liberties in the Arab World).

The Supreme Council for Islamic Affairs is concerned with reviewing all religious and preaching meetings and endorsing them among both Sunnis and ${ }^{22}$ Human Rights First. Bahrain: No More Excuses-Time for Radical Change. www.humanrightsfirst.org/wp.../pdf/Bahrain-No-More-Excuses.pdf.

${ }^{23}$ Public Liberties in the Arab World, Op. Cit., P. 75. 
Shiites. It also concerned with approving the supervision program for all citizens who study religion abroad, especially those who receive religious instruction in $\operatorname{Iran}^{24}$ (Public Liberties in the Arab World).

All places of worship need permission to establish and practice rites, some of which are delayed by permission, but religious groups have not mentioned a request that has been rejected, and even those who have not been granted a license to practice their rituals have not been harassed before obtaining a license.

What distinguishes the current situation in Bahrain is the fact that the Shi'a religious celebrations are allowed in Ashura, making it the only country in the region that gives them this right. The country enjoys official holidays on that occasion. The king ordered full coverage of the events of Ashura, and Bahrain was distinguished in this area externally, by allowing religious figures of any religion to visit the country, and to meet with any of the personalities of the government or civil leaders ${ }^{25}$ (International Religious Freedom Report, 2014-2017).

Articles (23) and (24) suggest that freedom of expression is limited in general, but is in growth and all official media broadcast one point of view, but some private newspapers and non-governmental publications criticize government policies on most issues, and the criticism of the ruling family remains rare. The Press Law of November 2002 limited the government's ability to prohibit the publication of press but implicitly required the prevention of activities that constitute propaganda for immoral behavior, and this gives entrance to the government to exert pressure on the media ${ }^{26}$ (Human Rights in the Arab World, 2009).

With regard to Article (26): There are no real restrictions on the freedom of correspondence, communications, and electronic communication, but the government has the authority to wiretap telephone calls and other private correspondence. The government also monitors the use of the Internet to prohibit access to sites deemed to be antigovernment or Islam, but the programs used for censorship are not reliable, often obscuring other sites that are not banned from use.

Article (27) has already been put in place, and many associations have been authorized by the government, including the Independent Human Rights Organization. The government has also allowed the establishment of branches in the country for international human rights groups, including Amnesty International $^{27}$ (Freedom House: Freedom in the World, 2003-2017).

In addition, the law prohibits the establishment of an independent labor union without the permission of the government. The law stipulated that the strikes should only be aimed at improving the economic and social conditions of the workers in order to remove the political objectives of that union. The strike is also prohibited in vital areas, such as: communications, electricity, water, hospitals, airports, and ports ${ }^{28}$ (Public Liberties in the Arab World). 
Article (28) is almost familiar, especially after the hurdle of religious meetings that have been a concern for the government authorities. Most of the abuses have been committed by both sides. However, some meetings remain sensitive, which sometimes causes the participants to be prevented, suspended, or harassed.

The text of Article (31) contains a very fine content that no new organization is entitled to negatively influence the essence of the right or freedom, but the actual practice of making laws does not limit the rights and freedoms. This is questioned by some of the laws that are issued, so that it can undermine the freedom of the press and the right of journalists to adopt certain views.

\section{Constitutional Texts and the Status of Human Rights in UAE}

The first provisional constitution was issued in the UAE in 1971. It states that the UAE system of government is a constitutional monarchy with a presidential system. In 1996, it was adopted as a final constitution after amendments. The exercise of the system of government in the state is like a federal system of federal monarchy, so that the President and Vice President are elected only by the seven governors of the seven members of the Supreme Council of the Union. The UAE Constitution consists of 10 sections and 151 articles $^{29}$ (UAE Constitution). Articles relating to human rights in the UAE are 10,11,21, 26, 28, 29, 30, $31,32,33,34,36,40$ and 41.

Since its inception, in theory, human rights and personal liberties are protected in the United Arab Emirates. The country's constitution and laws provide for basic liberties and promise a participatory democratic system.

Regarding Articles (10, 11, and 21): It seems that practical application is appropriate to its content, since, like all administrative and commercial matters, the UAE authorities are not expected to commit any irregularities.

Article (10) is of theoretical content, since one of the objectives of the UAE is to protect the rights and freedoms of the people of the Union and is certainly dependent on the practical reality. The same is true of Article (11). It is true that all these factors (equality, social justice, security and equal opportunities) are factors of social stability, but it is assumed that the formula should be provided to the UAE society, and its emergence in the laws emanating from the Constitution. Equality and equality of opportunity are based on granting all citizens the right to occupy public positions according to competence in an electoral or competitive framework that leads the competent to the higher echelons ${ }^{30}(\mathrm{Hu}-$ man Rights in the Arab World).

In terms of articles (26) and (28), the amount of personal freedom varies from one emirate to another according to the internal laws in force, but the exclusion of abuses, such as: the arrest, search, or detention of a person except in accordance with the provisions of the law remains relative, despite the prohibition of

${ }^{30}$ Human rights in the Arab World, Op.Cit. p.68. 
arbitrary detention in the Constitution. The UAE laws allow individuals to be held in solitary confinement if the police believe that their contact with a third party may affect ongoing investigations. The accused may remain in police custody without charge for an indefinite period of time on a judicial order, until the completion of the investigation, but torture and death as a result of the investigation are reportedly rare ${ }^{31}$ (Freedom House: Freedom in the World, 2003-2017).

Article (29) and Article (21) does not differ in the extent to which its content is compatible with the practical reality in the UAE or in the laws issued by its official bodies. However, the problem in the text of this article (and perhaps in the texts of other articles) is a need for restrictions on content that is not problematic in the state at the time of the drafting of the constitution and is not expected to be so at any time in the future. This is one of the achievements described by traditional thinkers who believe that there should be exceptions in every constitutional text, There is no problem with its openness on the one hand, nor does obligation exist in most of the materials, even though explicit, due to the lack of any force behind its application.

As for articles (30), (31) and (33), which affirm freedom of opinion and expression by all means-freedom of communication and freedom of assembly and association-what can be said is that freedom of expression is very limited in practice, and journalists and academics exercise self-censorship consistent with the outlines of official policy and national security. Religion and the state, while guaranteeing the freedom of traditional communications, both exercise monopoly over the Internet, obscuring what it does not want from websites ${ }^{32}$ (Human Rights in the Arab World).

The government also restricts the freedom of meetings and association. Permissions are required to allow organized popular gatherings, and they are rarely granted. Although the difference in flexibility is from one emirate to another, so political discussion sessions are held in private homes, and all non-governmental organizations must be registered with the Government. Even though a number of unregistered groups operate publicly, there are no independent groups of human rights. Laws also prohibit strikes and the formation of professional associations and independent trade unions. The decision of the UAE that considered Muslim Brotherhood as a banned and terrorist group resulted in the arrests of its supporters $^{33}$ (Bani Salameh, 2019, A). With regard to the content of article (32) on the freedom to practice religious rites, the government respects this right in practice, and does not interfere in private religion, but in turn controls all Sunni mosques, prevents proselytizing, and restricts the freedom of religious gatherings, in one way or another reducing the ability of religious groups that do not have a place to worship or performing rituals. The government recognized a

\footnotetext{
${ }^{31}$ Freedom House: Freedom in the World, country ratings 2003 through 2017: UAE.

${ }^{32}$ Human rights in the Arab World, Op.Cit. p.69.

${ }^{33}$ Mohammed Torki Bani Salameh. Muslim Brotherhood and the Jordanian State: Containment or Fragmentation Bets? (1999-2018). Asian Journal of Comparative Politics. December, 2019.

https://doi.org/10.1177\%2F2057891119891035.
} 
small number of Christian denominations and granted them plots of land with permission to build a number of churches. Three were granted permits and one was opened $^{34}$ (International Religious Freedom Report, 2012-2017).

With only $15 \%$ of UAE nationals in the Shiite community, the government only builds Sunni mosques, which make up $85 \%$ of the population, and appoints all Sunni imams. The government also provides guidance for religious preaching and monitors the political content of speeches in mosques, with the exception of the Emirate of Dubai, which does not appoint imams in the Shiite mosques in the country. The Shiite minority in the northern emirates has the freedom to worship and administer its own mosques, but it is a private place of worship, which receives no government support. In addition, Shiites in Dubai have a special judicial system in issues of personal status, which is managed by a special Shi'a council, rather than Sharia courts that apply the Sunni Maliki doctrine ${ }^{35}$ (Religion in the UAE).

Despite the tolerance and friendly atmosphere prevailing in the UAE in general with foreigners, who make up the vast majority of the country, and accepting other religions and religious rituals or cultural manifestations associated with their lives in the countries from which they came, the acceptance of Emirati people and government agencies to other non-Christian religious cultures is much less than the acceptance of Christian culture and associated religious rites. The softness of Islam may be related to that religion, as the religion of the former colonizer and contemporary civilization, and perhaps because Hindus and Buddhists in the country are less educated, less influential, and occupy functions of less importance.

Article (34) is also a problem-free article when applied. An additional provision appears to have been inscribed in it. It is not permissible to enslave anyone. Is it specific to the prohibition of slavery (slavery in its literal sense) or is it intended to prohibit inhumane working conditions that lead to imprisonment of the worker at his workplace, preventing him from his rights? If, in the first sense, there is no longer any manifestation of slavery, in the second sense, it will depend on the definition of working conditions that fall within this framework.

The provisions of Articles (36) and (40) are almost entirely relevant to the provisions of these constitutional articles, with a slight difference in the degree of abuses that may be experienced by foreigners in some emirates (in relation to article 40) due to the variation mentioned in the local laws of each Emirate.

Article (41) is procedural content, which shows the way to a person who has a grievance concerning the violation of rights and freedoms, but in this regard he is relying on what he gets after his grievance.

\section{Constitutional Texts and the Status of Human Rights in Oman}

Oman suffered a long period of isolation and stalemate during the reign of Sul-

\footnotetext{
${ }^{34}$ International Religious Freedom Report, ، 2012- 2017.UAE.

${ }^{35}$ Religion in the UAE. https://en.wikepedia.org/.../Religion-in-the-United-arab-Emi.
} 
$\tan$ Sa'id Bin Taymor (1938-1970). In 1970 Sultan Qaboos led a movement of change in the country ${ }^{36}$ (Bani Salameh, 2009). Sultan Sa'id was deposed and Sul$\tan$ Qaboos took office. The first popular participation in Oman began in 1981 with the formation of the Consultative Council. In 1996, the Omani Constitution was promulgated under the name of the Basic Law of the State. The Constitution of Oman consists of seven sections and 81 articles $^{37}$ (Constitution of the Sultanate of Oman). Articles on human rights in Oman's Constitution are 11, 18, 19, 24, 28, 29, 30, 31, 32, 33, 34 and 35.

Human rights conditions in Oman are quite poor overall. There is little respect for core civil and political rights such as freedom of expression, assembly and association. Peaceful dissent typically faces harsh repression. The administration of justice is highly personalized, with limited due process protections, especially in political and security-related cases.

Concerning the provisions of Article (11): Regarding economic principles, there are no problems with regard to its application or the laws issued in respect of it. It is a state that is open to trade and its economy is free, and these principles are not in contrast to the political orientations in the Sultanate.

The concepts of Articles (18)-(19)-(24) have good theoretical concepts, but the problem lies in the fact that most of these matters have not been enacted. The compatibility between the laws applied in the country, even after the promulgation of the Basic Law, and the contents of these articles concerning the rights of individual citizens, in particular, although the police do not need a warrant for arrest, and do not always respect the legal procedures for pre-trial detention, arbitrary detentions are rare, and if the accused in delicts or minor criminal cases, they have the right to appoint a lawyer. Public Defendants in cases involving State security are not open trial, lawyers are not allowed, and the respondent cannot appeal at all on national security or serious crimes ${ }^{38}$ (Freedom House: Freedom in the world, 2003-2017). Article (24) is characterized by its advanced content, which will be a bright point in the history of the Omani authorities in dealing with the citizens and residents of the country. These concepts are not found in the constitutions of the Gulf region, as the view of the people of the region to man is still governed by a holistic view of society, not an individual legal view $^{39}$ (Bani Salameh, 2009).

With regard to article (28), we find a return to the appeal and the restrictions on the freedom to perform religious rites, which must first be: in accordance with established customs; secondly, that they do not disturb public order; and thirdly, it is not contrary to etiquette, and all these restrictions are loose. They

\footnotetext{
${ }^{36}$ Mohammed T. Bani Salameh Democratic Change in the Sultanate of Oman: Status quo, Challenges and Future Horizons. Journal of the Gulf and Arabian Peninsula Studies, University of Kuwait, No. 135, Vol. 35, (October, 2009).

${ }^{37}$ Constitution of the Sultanate of Oman.

${ }^{38}$ Freedom House: Freedom in the world, country ratings 2003 through 2017: Oman.

${ }^{39}$ Bani Salameh, Mohammed Torki. (2009). Democratic Change in the Sultanate of Oman: Status quo, Challenges and Future Horizons. Journal of the Gulf and Arabian Peninsula Studies, University of Kuwait, No. 135, Vol. 35, October.
} 
can be interpreted by each person according to his or her wishes, and the freedom of religious rites, if they are meant to be other than Islam or non-mainstream religion, will certainly not be in accordance with established customs. However, the reality of the application of the text of this article is that non-Muslim groups perform their religious rites in churches and temples built on the territory provided by the Sultan, including two Catholic churches, two Protestant churches, and Hindu temples built in sites licensed on land provided by the Government, and buildings for Catholic and Protestant missions in Sohar and Salalah, but non-Muslim religious organizations must be registered with the government. The government also places some restrictions on their activities, especially missionary activities directed at Muslims. Citizens and residents have the freedom to discuss their religious beliefs, but without non-Muslims having the right to invite Muslims to their own beliefs, since non-Muslims have the right to enter Islam, but Muslims do not have access to another religion. The Omani authorities were directed warning to members of the Baha'i community not proselytizing to their religion ${ }^{40}$ (International Religious Freedom Report, 2012-2017: Oman).

A small percentage of the population is Hindu, Indian, as well as a small number of Christian citizens who came from India or Eastern Mediterranean countries obtained Omani citizenship. This may be explained by the fact that the religions practiced in a given role of the state, in addition to Islam, are Christian and Hindu ${ }^{41}$ (International Religious Freedom Report, 2012-2017: Oman).

As for the articles (29) and (31) freedom of opinion and expression by all means of expression, freedom of the press, printing, and publishing, is an unbelievable statement of means of application. Freedom of expression is very limited, and all the private media is owned by the state and gives only a formal point of view; private radio and television broadcasting are not allowed, but satellite television dishes are allowed, and the law prohibits criticism of the Sultan and imposes censorship on domestic or imported publications, although, journalists usually practice self-censorship. The press and publishing law allow for prevention of publications, whether politically or culturally offensive or sexual$\operatorname{ly}^{42}$ (Human Rights in the Arab World).

Article (30) does not appear to require monitoring of postal and telegraphic correspondence, but although the Basic Law was issued in 1996, it has not been subjected to electronic communications, which have become the most widely used means, the means by which freedom is violated. Only Oman Telecom has become the official agent for Internet services since 1997. The company controls Internet sites and intercepts information before reaching the users of the network.

Articles (32) and (33) can be said to be relative in the context of the situation and are not defined by fixed frameworks. All public gatherings must be permit-

\footnotetext{
${ }^{40}$ International Religious Freedom Report, Oman, 2012-2017.

${ }^{41}$ International Religious Freedom Report: Oman, 2012-2017.

${ }^{42}$ Human rights in the Arab World, Op.Cit. p.147.
} 
ted by the government, although this rule is no longer fully enforced and associations need to be registered by the government. There is no activity of independent political groups or organizations of human rights. The law prohibits all types of trade unions or professional associations and prohibits strikes ${ }^{43}$ (Bani Salameh, 2009).

\section{Constitutional Provisions and the Status of Human Rights in Qatar}

The first constitution was promulgated in Qatar in 1971, under the name of an interim constitution, consisting of 77 articles dealing with the system of government and the organization of powers and the determination of their competencies as well as the rights and duties of citizens. In 2003, the provisional statute was abolished, and a new constitution was adopted. It embodies popular participation in decision-making and guarantees the rights and freedoms of citizens. The Qatari Constitution consists of five sections and 150 Articles $^{44}$ (Qatar Constitution). Articles on human rights in $^{45}$ Qatar's constitution are 18, 26, 27, 36, 37, 44, 45, 46, 47, 48, 50 and 146.

The state of human rights in Qatar is almost the best in the Gulf area, Qatar has enshrined the rule of law and human rights in its Constitution and national strategic frameworks. It has also enacted a range of laws aimed at strengthening human rights and the judicial system, including judicial independence.

However, the relative advantages associated with the text of the articles of the Constitution and their formulations are not necessarily indicative of the positives of application, especially since the new constitution is very modern. Many of the laws relating to its articles have not yet been issued, and the problems of its applications have not yet appeared on the surface.

Article (18) The Constitution describes the values of Qatari society, which are humanitarian demands that the legislator cannot impose. All that he can do is issue laws that protect abuses against them. These are relative issues, especially in the form of charity and morality.

The freedom to dispose of private property and business (the contents of articles 26 and 27) does not pose any obstacles to implementation, because Qatar follows the free economy model, and there are no restrictions on the movement of trade or private property of individuals. All that is needed in the economic legislation in this regard are the organizations related to the realization of the principle of social justice, which was stipulated in exchange for freedom of economic activity.

We then find out about rights and personal freedom Articles $(36,37)$, and it has a special character, because it defines the framework in which the authorities ${ }^{43}$ Bani Salameh, Mohammed Torki. (2009). Democratic Change in the Sultanate of Oman: Status quo, Challenges and Future Horizons. Journal of the Gulf and Arabian Peninsula Studies, University of Kuwait, No. 135, Vol. 35, October.

${ }^{44}$ Qatar Constitution.

${ }^{45}$ Qatar Constitution. 
are supposed to deal with the individual in his/her body and his/her moral character. With regard to the applicable laws and the Qatari reality, the country has a good record in this regard. In recent years, the law prohibits arbitrary arrest and detention, although there are cases of detention and prolonged pre-trial detention of citizens and foreigners in security cases, but most aspects of personal freedom are protected; insults are not directed at the accused, and the security authorities do not treat them as criminals. In recent years, there have been no registered cases of torture of those concerned, and detainees receive legal advice $^{46}$ (Qatar Constitution).

In articles $(46,52)$, reference is made to a non-infringing personal right. First, the Constitution gives everyone the right to address public authorities. The second provides for the right to protect the resident in his or her right, and all articles are compatible with the practical reality in the country in general.

In regard to collective freedoms, articles 44 and 45 are concerned with the issue, and both affirm the right of citizens to assemble and guarantee freedom of association, but the reality is contrary to that. Public demonstrations are completely prohibited, despite the tolerance of some anti-Israel marches. Freedom of association is limited to the fact that the founding group has a social, cultural, or professional orientation and must be registered with the government, and political parties do not exist ${ }^{47}$ (Beydoun, 2012).

Articles (47) and (48) cover freedom of opinion and scientific research on the one hand, and freedom of the press, printing, and publishing on the other, but freedom of expression is limited. Official media do not deviate from the framework desired by the government. Independent media do not receive instructions, but they exercise self-censorship away from clash with the authorities ${ }^{48}$ (Human rights in the Arab World). Even Al-Jazeera, which has gained worldwide acclaim as it broadcasts leftist political views of governance, does not deal with Qatar's internal affairs much ${ }^{49}$ (Freedom House Freedom in the world, 2012-2017).

Article (50) refers to the freedom of worship, and describes it as guaranteed freedom to all. This is true if it does not include the last word. The other groups (Shiites, Christians, and other religions), which were mentioned in the analysis of discrimination due to religion, which progressively ranks in this order after the Sunni sect, all of whom do not have the freedom to worship as they want. The Shi'a minority are permitted to practice their rituals only in the homes of their followers. The introduction of religious books and tools for worship is not officially permitted, but they enter the country with individuals in private. It is worth mentioning that Islamic education is compulsory in public schools, but there are no restrictions on non-Muslim religious education in private lessons ${ }^{46}$ Ibid.

${ }^{47}$ Nasser M. Beydoun. The Glass Palace: illusions of Freedom and Democracy in Qatar, Algara publishing. 2012-2017.

${ }^{48}$ Human rights in the Arab World, Op.Cit. p167.

${ }^{49}$ Freedom House: Freedom in the world, country ratings Qatar 2012-2017. 
for children; mostly foreign children are learning in secular private schools ${ }^{50}$ (International Religious Freedom Report 2012-2017: Qatar).

Article (146) of the Constitution stipulates that the provisions on rights and freedoms may not be amended, except within the limits that are intended to grant more rights and guarantees in favor of the citizen. In reality-albeit theoretically - there is a brake on the reactionary intentions that want to target freedoms wherever they exist and seek to reduce them.

\section{Constitutional Texts and the Status of Human Rights in Saudi Arabia}

The first draft of a constitutional project was drawn up in Saudi Arabia in 1960, but this project was abolished. In 1992, the Basic Law was passed, which consists of 83 articles divided into 9 sections ${ }^{51}$ (Saudi Constitution). Articles on human rights $^{52}$ in Saudi constitution are 18, 19, 26, 36, 37, 39, 40 and 43.

Saudi Arabia's human rights record is among the worst all over the world. The authorities severely restricted the rights to freedom of expression, association and assembly. Many human rights defenders and government critics, including women's rights activists, were arbitrarily detained.

As for the economic principles embodied in Articles $(18,19)$, there is consistency between the contents of these articles and the prevailing laws on the one hand, and practical applications on the other. Private ownership and the foundations of an open economic system are not exposed to the free economy applied by Saudi Arabia in full. There are also no direct forms of encroachment on people's property, or confiscation without judicial judgment.

Article (26) states that the State protects human rights in accordance with Islamic law. This is a general framework of Article 1, 7 and 8, and many of the articles of this Constitution specify the Shari'a as a designation to everything, but what are these human rights protected by the state? This article should, at least in its broad outlines, be defined so that the citizen and the resident know what freedoms are guaranteed by the state in accordance with Shari' ${ }^{53}$ (Freedom of Religion in Saudi Arabia).

The problem in such constitutional texts may be that Islamic law does not have freedoms for citizens or residents, but there are freedoms for Muslims and non-Muslims. This is why the linking of public liberties with sharia law is problematic in the lives of the citizens and residents of the modern state, which are no longer connected to the boundaries of the religious state, as in the Middle Ages. The Muslims are from different countries and have different systems and freedoms that cannot be granted to citizens of another country because they are Muslims. In fact, these efforts did not protect Muslims other than the dominant group or the non-Muslims. They also allowed Islamic organizations or some of

\footnotetext{
${ }^{50}$ International Religious Freedom Report: Qatar. 2012-2017.

${ }^{51}$ Saudi Constitution.

${ }^{52}$ Saudi Constitution.

${ }^{53}$ Freedom of Religion in Saudi Arabia. www.arabicbibla.com.
} 
their activists to spread the culture of Islamic globalization, so that the issues of Afghanistan, Chechnya, and others became a local priority. As the protection of human rights is in accordance with Islamic law, it does not differentiate between an Afghan Muslim or a Russian and a Saudi Muslim.

In fact, there is no protection of religious freedom at all except for the Wahhabism. The government prohibits non-Muslims from openly practicing their religious rituals, and even in private homes, sometimes raiding those sites where they perform their religious rites, banning non-Muslim religious books and symbols of religious affiliation to any of the other religions. It is also forbidden to publish any religious document that is contrary to any of the principles of the Wahhabi school, including other Islamic books, and the violation of this leads to the most severe types of harm ${ }^{54}$ (Freedom of Religion in Saudi Arabia).

Article (36) states that the state guarantees the security of the citizen and the resident, and cited the number of freedoms that are supposed to be provided to citizens and residents, but it does not mention the word "freedom" for the sensitivity of the political system, and the mention of this word is in the general context.

It is interesting to note that the section that precedes the enumeration of the freedoms of citizens and personal residents in all the constitutions of the GCC states (some of which are in a separate article) is that the expression "personal freedom" is guaranteed, which was replaced here with: "The State provides security to all its citizens and residents on its territory."

As for the application, there are many observations on the contents of this article. The Saudi citizen and non-Western residents have no protection against arbitrary arrest, extension of detention, or torture by the security authorities. Although the new criminal laws prohibit torture, and prevents arrest before charge for more than five days, the application contravenes those theoretical laws ${ }^{55}$ (Freedom House: Freedom in the world, 2014-2017).

The violations of this article are not limited to security men only, but the $\mathrm{Mu}$ tawa'een also force people to believe what each of them believe in the correct form of social behavior or religious behavior or personal dress. They make sure that all shops are closed at prayer times, outside the mosque, and those who are not dressed properly, along with any man or woman who are suspected to be unmarried are to be imprisoned or investigated ${ }^{56}$ (Human rights in the Arab World).

The authorities have recently reduced the powers of the mutawwa'in, so that they will not imprison anyone for more than 24 hours, unless their fault is that their behavior or dress is inappropriate, but sometimes they overpass this article before handing people over to the police.

The other side that violates this article is the immigration authorities, which monitor the activities of Shiite citizens and their contacts abroad, especially Iran,

${ }^{54}$ Freedom of Religion in Saudi Arabia. Ibid.

${ }^{55}$ Freedom House: Freedom in the world, country ratings 2002، through 2014-2017: Saudi Arabia.

${ }^{56}$ Human rights in the Arab World, Op. Cit. p.102. 
after the Iranian revolution in 1979, to limit their travel to Shiite shrines for security reasons, and those who traveled to Iran without the permission of the authorities, had their passports confiscated and were prevented from traveling for two years. The ban was lifted in 2001, but was replaced by travel to Iraq ${ }^{57}$ (Bani Salameh, 2019, B).

Article (39) has been repeated in the constitutions of all GCC countries in terms of freedom of opinion and expression, freedom of the press, printing and publishing. It has been developed in two articles, one on the aspects of freedom of individual expression and scientific research, and the other on the freedom of the press, combining them into one substance, but this country has its own peculiarity, such as the freedom of opinion and freedom of the press; a peculiarity that is reflected in the conservative formulation of this article. Instead of the fact that the constitution gives the media an area that restricts it to the media and publishing and all means of expression, the government controls all the local media, and there are censorship bodies that follow unwanted local and foreign newspapers in their press articles. It also monitors books published at home so that they conform to the standards imposed by the supervisors, often dealing with matters of politics, religion, and some sensitive social issues ${ }^{58}$ (Public Liberties in the Arab World).

The rest of the frameworks of expression of opinion and positions such as strike, and the formation of professional unions that negotiate collectively are not allowed. The right to demonstrate for political rights is completely prohibited, whatever the motives or objectives of the demonstration, including demonstrations against Israel. The formation of professional associations must not first of all be of a political nature and must have a complex government authorization, which is extended for several years, and the institutional names play a role in approving them or not. The formation of political parties, intellectual groups, or trade unions is strictly forbidden ${ }^{59}$ (Public Liberties in the Arab World).

As for the publication of books, it is necessary to present the draft of the book to the Ministry of Information for permission to print. After printing, the author returns to the Ministry of Information again to obtain the final release.

Article (40) provides that telegram, postal, telephone, and other means of communication are protected, but it is well known from the practical reality in the country that customs officers open external mail when they arrive at the outlets, to check their contents, confiscate what is on their block lists, and see the contents of the incoming mail. They also write on the circumstance that it has been opened by official bodies. It is not understood that there is a digression in the text of the article: It is not permissible to confiscate, delay, review or listen to it. It is strange that some of the Ministry of Interior staff involved in this matter

${ }^{57}$ Mohammed Bani Salameh. Migration from the Arab Spring Countries to Europe: Causes and Consequences: IEREK Interdisciplinary Series for Sustainable Development 10.1007/978-3-030-01659-3_28.

${ }^{58}$ Public Liberties in the Arab World, Op. Cit., P. 107.

${ }^{59}$ Ibid. P.108. 
and their relatives boast that they know the secrets of other families, who may be on watch lists, and may be exploiting the sites that those employees wanted to snoop on the news of others out of curiosity, or a desire to spread the secrets of others. There is also electronic censorship on the Internet by the King Abdulaziz City for Science and Technology, which controls the blocking of pages that the authorities do not want to inform the public, but some institutions are excluded from blocking, such as; the Economic Council or the specialized hospital ${ }^{60}(\mathrm{Hu}-$ man Rights in the Arab World).

Article (43) of the Constitution establishes the Council of the King and the Crown Prince as institutions that screen citizens' grievances. They are partially doing so, but the problem is that it is an unorganized process that consumes time and effort and does not reach everyone. It does not guarantee fair procedures and quick solutions from the two institutions. If it were to be organized by the Constitution, it would have been better than this tribal form, which is predominated by the nature of filing a complaint, and then coming to provide a message, and obtaining the right guaranteed to the citizen without insult and long waiting.

Some say that the Saudis believe that personal petitions have achieved the desired purpose. In the 1970s, it was difficult to organize public gatherings and take collective steps. There was no need for a Saudi citizen to join any group, since every Saudi can have access to any official whatsoever, including the King. In these public gatherings, a citizen can file a petition with the governor. Even if quick steps are not taken, at least the promise of justice will remain, but as time passed, it gradually began to wane ${ }^{61}$ (Kishishian, 2002).

\section{Conclusion and Recommendation}

At the conclusion of this study, it can be concluded that there is no shortage of laws and the constitutional provisions of some of these states that emphasize human rights and show the rights and duties of citizens, to the extent that the scientifically more pessimistic are inclined to them, but they remain theoretical texts $^{62}$ (Bani Salameh, 2017).

This reality is manifested in several forms: one is the lack of differentiation between state systems or their constitution and the philosophy of government or programs adopted by the ruling authorities in successive periods. Constitutions are contractual formulas developed by societies in the spirit of society, but the philosophical theorization in the government of a period of time and specific programs for the management of the country are temporary things that end by the end of the government, and it remains the fixed things that the society decided in its civil institutions that are laws related to the state entity, and they

${ }^{60}$ Human rights in the Arab World, Op.Cit.p.102.

${ }^{61}$ Joseph Kishishian: Caliphate in Saudi Arabia: Translated by: Ghada Haidar, Beirut, Dar Al-Saqi, 2002.p.185.

${ }^{62}$ Mohammed Torki Bani Salameh. Political Reform in Jordan: Reality and Aspirations. World Affairs Journal. Vol.180, winter. (2017). https://doi.org/10.1177/0043820018765373. 
usually require modification, which is long procedures and requires a great majority in the state. The Gulf constitutions have many exceptions in most of the constitutional texts in those countries, which relate to giving citizens their rights or allowing any freedoms, which rid those texts of their value and lead to violation of the Constitution by making the exception the rule. (Except in cases specified by law), freedom and confidentiality of postal, telephone and telegraph communications (except in cases prescribed by law), inviolability of dwellings, the role of science and worship (except in cases prescribed by law), even in freedom to perform religious rituals, we find exceptions and limitations. They must be first: according to established customs, and secondly, do not disturb public order, and third, there is no objection to morals. All these restrictions are broad and can be interpreted by everyone according to their desires. The freedom of religious rites, if they are intended to be other than Islam or non-mainstream, will certainly not be-in accordance with established customs. Finally, we note that the reality of economic, social and cultural rights in the Arab Gulf states is better than that of civil and political rights. It is important to note that all human rights are equally important and one cannot be enjoyed without full enjoyment.

In light of the findings of this study, the researcher recommends the following:

First: Urge the GCC States to take care of the issues of human rights for citizens and non-citizens. This requires the revision of the constitutions and legislations of these countries so that the constitutional texts and legislations contain clear legal obligations consistent with the values and principles of human rights and means of implementation to ensure the effective recognition of human rights and their respect.

Second: Establishment of national institutions for the education and dissemination of the culture of human rights and strengthening the role of established ones in some GCC countries. The efforts to complete national plans are in cooperation with local and regional Arab human rights organizations.

Third: Inclusion of human rights in university education and postgraduate studies, promotion of master's and doctorate research in the field of human rights, inclusion of human rights in literacy curricula, and various non-formal education programs.

Fourth: Urging the print, visual and audio-visual media to promote the values of human rights, pluralism, and diversity and to avoid anything that would fuel racial or religious hatred, defame the other opinion, or violate human dignity.

Fifth: Urge governmental and non-governmental human rights institutions to make maximum use of the media-especially the visual and audiovisual media-to spread the culture of human rights, including the establishment of platforms and special programs, and the use of modern technologies for this purpose, and work on the study of the components of popular culture, which constitute the awareness of the human to communicate to the appropriate discourse to spread the culture of human rights. 
Sixth: To call on intellectuals, politicians, and clerics in the GCC countries to refrain from inciting religion in cross-border relations with human rights, and to consider the rights provided for in the Universal Law as the minimum that cannot be derogated from by cultural or other suits, on the rooting of the values of human rights in Arab cultural traditions.

Seventh: Inviting academics, researchers, and jurists to work on highlighting the roots of human rights in Arab culture and highlighting the contribution of Islamic and Christian civilization to the establishment of the values of human rights and highlighting the artificialization of some of the principles of human rights.

\section{Conflicts of Interest}

The author declares no conflicts of interest regarding the publication of this paper.

\section{References}

Abdul Qader, W. (2011). The Kuwaiti Election Law, a Critical Reading of Concerns and Influences of the Democratic Experience. Arab Journal of Political Science, No. 31, 111-143.

Abdullah, A. K. (2012). The Arab Spring Implications for GCC Countries. Doha: Arab Center for Research and Policy Studies. (In Arabic)

Al-Asiri, A. al-R. A. (2007). Islam in the Constitutions of the Gulf Cooperation Council Countries. Arab Journal of Political Science, No. 13, 8-35. (In Arabic)

Al-Awadhi, B. A. (1990). GCC Countries and International Levels of Work. Knowledge World Series, No. 85, 5-12. (In Arabic)

Al-Galum, Y. (1966). The Influence of the Dwyane on the Process of Political Participation in Kuwait. Journal of Social Sciences, Kuwait, No. 3. (In Arabic)

Al-Hamouri, M. (2010). Rights and Freedoms between the Ambitions of Politics and the Obligations of the Constitution: The Case of Jordan. Amman: Dar Wael Publishing and Distribution. (In Arabic)

Alloush, N. (2002). Public Liberties in the Arab World, Human Rights in Arab Thought: Studies in Texts. Beirut: Center for Arab Unity Studies. (In Arabic)

Al-Najjar, G. (2000). Introduction to Political Development in Kuwait (p. 3). Kuwait: Dar Qurtas for Publishing. (In Arabic)

Al-Serhan, S. F. et al. (2017). Challenges Facing National Security in the Gulf States: A Case Study of Bahrain. International Journal of Humanities and Social Science, 7, 131-142.

http://www.ijhssnet.com/view.php?u=http://www.ijhssnet.com/journals/Vol_7_No_12 _December_2017/15.pdf

Al-Shawi, M. (2006). General Theory in Constitutional Law. Amman: Dar Ward Publishing and Distribution. (In Arabic)

Azzam, F. S. (1995). Civil and Political Rights Guarantees in Arab Constitutions: Comparative Study. Cairo: Cairo Institute for Public Liberties Studies.

Bahrain Constitution.

Bani Salameh, M. (2019b). Migration from the Arab Spring Countries to Europe: Causes 
and Consequences. In Smart Technologies and Innovation for a Sustainable Future (pp. 243-254). Berlin: Springer. https://doi.org/10.1007/978-3-030-01659-3_28

Bani Salameh, M. T. (2009). Democratic Change in the Sultanate of Oman: Status Quo, Challenges and Future Horizons. Journal of the Gulf and Arabian Peninsula Studies, $35,77-105$.

Bani Salameh, M. T. (2017). Political Reform in Jordan: Reality and Aspirations. World Affairs Journal, 180, 47-78. https://doi.org/10.1177/0043820018765373

Bani Salameh, M. T. (2019a). Muslim Brotherhood and the Jordanian State: Containment or Fragmentation Bets (1999-2018). Asian Journal of Comparative Politics, 20, 1-19. https://doi.org/10.1177/2057891119891035

Bani Salameh, M. T., \& Al-Sharah, M. K. (2011). Kuwait's Democratic Experiment: Roots, Reality, Characteristics, Challenges, and the Prospects for the Future. Journal of Middle Eastern and Islamic Studies, 5, 57-81. (In Asia) https://doi.org/10.1080/19370679.2011.12023185

Bani Salameh, M. T., \& Ananzah, A. A. (2015). Constitutional Reforms in Jordan: A Critical Analysis. Digest of Middle East Studies, 24, 139-160. https://doi.org/10.1111/dome.12068

Bani Salameh, M. T., \& Darawshehl, S. A. (2018). Human Rights in the Jordanian Constitution: Between Theoretical Texts and Practical Application. International Journal of Human Rights and Constitutional Studies, 6, 70-88.

https://doi.org/10.1504/IJHRCS.2018.091658

Beydoun, N. M. (2012). The Glass Palace: Illusions of Freedom and Democracy in Qatar. New York: Algora Publishing.

Constitution of the Sultanate of Oman.

Freedom House: Freedom in the World, Country Ratings 2003 through 2014-2017: UAE.

Freedom House: Freedom in the World, Country Ratings 2003 through 2014-2017: Oman.

Freedom House: Freedom in the World, Country Ratings 2003 through 2014-2017: Bahrain.

Freedom House: Freedom in the World, Country Ratings 2003, through 2014-2017: Saudi Arabia.

Freedom House: Freedom in the World, Country Ratings Qatar 2012-2017.

Freedom of Religion in Saudi Arabia.

https://www.arabicbible.com/for-christians/160-oman/1438-freedom-of-religion-in-sa udi-arabia.html

Human Rights First. Bahrain: No More Excuses-Time for Radical Change. https://www.scribd.com/document/75919412/Bahrain-No-More-Excuses

Human Rights in the Arab World (2009). Report of the Arab Organization for Human Rights on the State of Public Liberties in the Arab World, Center for Arab Unity Studies. (In Arabic)

International Religious Freedom Report 2012-2017: Qatar.

International Religious Freedom Report 2014-2017: Bahrain.

International Religious Freedom Report, 2012-2017: Oman.

International Religious Freedom Report, 2012-2017: UAE.

Kishishian, J. (2002). Caliphate in Saudi Arabia (Translated by Ghada Haidar, Beirut, and Dar Al-Saqi). 
Kuwaiti Constitution.

\section{Qatar Constitution.}

Religion in the UAE. https://en.wikepedia.org/.../Religion-in-the-United-arab-Emi Saudi Constitution.

UAE Constitution. 